\title{
PENGARUH PENGGUNAAN COOPERATIVE LEARNING TIPE THINK- PAIR-SHARE (TPS) TERHADAP HASIL BELAJAR KEWIRAUSAHAAN SISWA KELAS X SEMESTER GENAP SMK KARTIKATAMA 1 METRO T.P 2015/2016
}

\author{
SafitriKurnia Lestari ${ }^{1)}$ Ningrum $^{2)}$ \\ Program Studi Pendidikan Ekonomi FKIP Universitas Muhammadiyah Metro \\ Nigrum34@yahoo.co.id
}

\begin{abstract}
Abstrak
Metode cooperative learning tipe think-pair-share merupakan model pembelajaran yang melibatkan peserta didik secara maksimal dalam kegiatan pembelajaran mulai dari merencanakan topik-topik yang akan dipelajari, bagaimana mendiskusikan topik suatu materi, hingga melakukan presentasi kelompok dan evaluasi. Adapun yang menjadi masalah dalam penelitian ini yaitu " Masih banyak peserta didik yang belum tuntas hasil belajar pada mata pelajaran kewirausahaan peserta didik kelas X semester genap SMK Kartikatama 1 Metro tahun pelajaran 2015/2016". Adapun tujuan dalam penelitian ini adalah untuk mengetahui pengatuh penggunaan model Cooperative Learning Tipe Think-Pair-Share(TPS) terhadap hasil belajar kewirausahaan pada kelas X semester genap SMK Kartikatama 1 metro tahun pelajaran 2015/2016. Maka hipotesis dalam penelitian ini adalah sebagai berikut: "Ada pengaruh positif pengunaan model Cooperative Learning TipeThink-Pair-Share terhadap hasil belajar kewirausahaan peserta didik kelas X semester genap SMK Kartikatama 1 Metro tahun pelajaran 2015/2016”. Populasi dalam penelitian ini wilayah yang sebanyak 3 kelas dengan jumlah 71 peserta didik. Sampel dalam penelitian ini adalah kelas X AK 1 yang berjumlah 24sebagai kelas eksperimen dan kelas X AK 2yang berjumlah 21 sebagai kelas kontrol. Setelah dianalisis hasil penelitian dapat disimpulkan bahwa dari analisis perhitungan nilai $t_{\text {hitung }}>t_{\text {tabel }}$ dapat dilihat pada daftar $\mathrm{G}$, pada daftar signifikan 5\% yaitu 9,10>1,72. Dan pada taraf signifikan 1\% yaitu 9,10>2,51. Dengan demikian hipotesisnya berbunyi bahwa : ada pengaruh positip penggunaan Cooperative Learning Tipe Think-Pair-Share (TPS) dapat meningkatkan hasil belajar kewirausahaan siswa kelas X AK 1 semester genap SMK Kartikatama 1 metro tahun pelajaran 2015/2016 pada pokok bahasan mengelola konflik. Siswa yang dinyatakan tuntas dengan KKM (75) setelah treatment sebanyak 14 siswa atau sebesar 58,33\% dan siswa yang dinyatakan belum tuntas sebanyak 10 siswa atau sebesar 41,67\%. Oleh karena itu untuk meninkatkan hasil belajar siswa, guru dapat menerapkan penggunaanCooperative Learning Tipe Think-Pair-Share(TPS) dalam pembelajaran yang di selenggarakan.

Kata kunci : Model pembelajaran Cooperative Learning TipeThink-Pair-Share (TPS) dan Hasil Belajar

PENDAHULUAN

Pendidikan pada dasarnya merupakan suatu proses membantu manusia

mengembangkan dirinya sehingga mampu

menghadapi gejala perubahan dan permasalahan dengan sifat terbuka dan


kreatif keberhasilan pendidikan akan sangat berpengaruh terhadap peningkatan kualitas manusia dan masyarakat suatu bangsa. Negara dikatakan maju dalam segala bidang baik dalam bidang ekonomi, teknologi, pertanian atau yang lainnya tidak lepas dari peran pendidikan, hal ini dikarenakan orang cerdas atau berpendidikan akan dapat memberikan kontribusi yang positif kepada negara.

Pendidikan nasional berfungsi mengembangkan kemampuan dan membentuk watak serta peradaban bangsa yang bermartabat dalam rangka mencerdaskan kehidupan bangsa, bertujuan untuk berkembangnya potensi peserta didik agar menjadi manusia yang beriman dan bertakwa kepada Tuhan Yang Maha Esa, berakhlak mulia, sehat, berilmu, cakap, kreatif, mandiri, dan menjadi warga negara yang demokratis serta bertanggung jawab.

Pendidikan merupakan ujung tombak pengukuran martabat suatu bangsa dimanapendidikan merupakan cara yang digunakan untuk mengangkat martabat dalam rangka mencerdaskan kehidupan bangsa sebagai mana telah tercantum dalam Undang-Undang Dasar Negara Republik Indonesia .

\section{2}

JURNAL PROMOSI Jurnal Pendidikan Fkonomi UM Metro
Guru sebagai tenaga pendidik harus dapat mengembangkan potensi siswa secara optimal dengan kemampuan untuk berkreasi ,mandiri, bertanggung jawab dan dapat memecahkan masalah-masalah yang di hadapi dan dimiliki karakter yang baik sehingga nantinya dapat melaksanakan fungsinya sebagai warga negara dalam memberdayakan siswa secara optimal maka tidak terlepas dari pembelajaran yang sesuai dengan karakteristik siswa itu sendiri.

Dari hasil observasi yang peneliti laksanakan di SMK Kartikatama1 Metro guru menggunakan berbagai macam metode dalam proses pembelajaran. Metode yang digunakan antara lain, metode ceramah, dan diskusi. Pada dasarnya guru sudah melaksanakan pembelajaransesuai dengan yang seharusnya di terapkan saat proses pembelajaran seperti menyampaikan tujuan penbelajaran, menyampaikan standar kompetensi dan kompetensi dasar dan memberikan tugas tetapi pada saat proses pembelajaran berlangsung siswa kurang begitu mengkondisikan diri sehingga susana kelas menjadi kurang begitu kondsif untuk melaksanakan kegiatan pembelajaran Hal ini akan berakibat rendahnya hasil belajar Kewirausahaan siswa dimana KKM mata pelajaran kewirausahaan adalah 70.Nilai 
Semester ganjil, siswa yang memperoleh nilai dari $\geq 70$ sebanyak 7 siswa dari 27 , artinya hanya 7 siswa atau $25,92 \%$, siswa yang telah mencapai ketuntasan dalam belajar sementara siswa yang memperoleh $<70$ sebanyak 20 siswa, yang berarti bahwa 20 siswa atau $74,08 \%$ belum mencapai ketuntasan belajar. Hal ini masih jauh dari apa yang diharapkan yaitu $75 \%$ hasil belajar siswa dapat memenuhi kriteria ketuntasan minimal (KKM).

\section{Think-Pair-Share (TPS) merupakan} metode yang menempatkan guru sebagai motivator, fasilitator, mediator, evaluator dan pembimbing, sedangkan siswa dalam kegiatan pembelajaran di dalam kelas memiliki peran aktif. Think-pair-share (TPS) menghendaki siswa untuk bekerja sendiri dan bekerja sama saling membantu dengan siswa lain dalam suatu kelompok kecil. Maka dengan menggunakan model pembelajaran Cooperative Learning Tipe Think-Pair-Share (TPS) diharapkan dapat digunakan untuk memingkatkan ketuntasan belajar siswa khususnya mata pelajaran kewirausahaan.

\section{KAJIAN PUSTAKA}

1. Model Cooperative Learning tipe Think-Pair-Share (TPS)
Pembelajaran kooperatif dimana siswa diberi masalah kemudian siswa berfikir secara individu, lalu berinteraksi dengan pasangannya dan berdiskusi untuk berbagi informasi. Strategi ini dilakukan untuk mengefektifkan pembagian informasi.

Menurut Ibrahim (2000:3) mengemukakan bahwa TPS (Think-Pair-Share) atau (berfikirberpasangan-berbagi) merupakan jenis pembelajaran kooperatif yang dirancang untuk mempengaruhi pola interaksi siswa. TPS menghendaki siswa bekerja saling membantu dalam kelompok kecil (2-6 anggota) dan lebih dirincikan oleh penghargaan kooperatif, dari pada penghargaan individual .

Sedangkan yang dikemukakan oleh Lie (2002:57) adalah:

Think-Pair-Shareadalah pembelajaran yang memberi siswa kesempatan untuk bekerja sendiri dan bekerjasama dengan orang lain. Dalam hal ini, guru sangat berperan penting untuk membimbing siswa melakukan diskusi, sehingga terciptanya suasana belajar yang lebih hidup, aktif, kreatif, efektif dan menyenangkan.

Dari kutipan tersebut dapat di ambil pengertian bahwa model Cooperative 
Learning TipeThink-Pair-Share (TPS) adalah di awali dengan proses berfikir (Think), siswa berfikir terlebih dahulu terhadap masalah yang di sajikan guru, kemudian berpasangan (Pair), siswa diminta untuk membentuk pasangan atau kelompok untuk mendiskusikan apa yang sebelunnya di pikirkannya secara mandiri dan diakhiri dengan berbagi pada kelompok yang lainnya (Share) setelah tercapai kesepakatan tentang pikirannya, maka salah satu pasangan membagikan kepada seluruh kelas apa yang menjadi kesepakatannya dalam pasangan tersebut, kemudian dilanjutkan dengan pasangan lainnya sehingga semua pasangan dapat melaporkan mengenai berbagai pengalaman atau pengetahuan yang telah dimilikinya.

a. Tahapan dalam Cooperative Learning tipe Think-Pair-Share (TPS)

Menurut Ibrahim (2000: 26-27) tahapan dalam pembelajaran Think-Pair-Share sebagai berikut:

Tahap 1 : Think (berpikir)

Guru mengajukan pertanyaan atau isu yang berhubungan dengan pelajaran. Kemudian siswa diminta untuk memikirkan pertanyaan atau isu tersebut secara mandiri untuk beberapa saat.

Tahap 2 : Pairing
Guru meminta siswa berpasangan dengan siswa lain untuk mendiskusikan apa yang telah dipikirkannya pada tahap pertama. Dalam tahap ini, setiap anggota pada kelompok membandingkan jawaban atau hasil pemikiran mereka dengan mendefinisikan jawaban yang dianggap paling benar, paling meyakinkan, atau paling unik.

Biasanya guru memberi waktu 4-5 menit untuk berpasangan.

Tahap 3 : Share (berbagi)

Pada tahap akhir, guru meminta kepada pasangan untuk berbagi dengan seluruh kelas tentang apa yang telah mereka bicarakan. Keterampilan berbagi dalam seluruh kelas dapat dilakukan dengan menunjuk pasangan yang secara sukarela bersedia melaporkan hasil kerja kelompoknya atau bergiliran pasangan demi pasangan hingga sekitar seperempat pasangan telah mendapat kesempatan untuk melaporkan.

Sementara Menurut Muslimin (Rosmiani, 2009:26) menyatakanbahwa langkah-langkah Think-Pair-Share ada tiga yaitu :Berpikir (Thinking), berpasangan (Pair), dan berbagi (Share).

Tahap 1 : Thinking (berpikir) 
Kegiatan pertama dalam Think-PairShare yakni guru mengajukan pertanyaan yang berhubungan dengan topik pelajaran. Kemudian siswa diminta untuk memikirkan pertanyaan tersebut secara untuk beberapa saat. Dalam tahap ini siswa dituntut lebih mandiri dalam mengolah informasi yang dia dapat.

Tahap 2 : Pairing (berpasangan)

Pada tahap ini guru meminta siswa duduk berpasangan dengan siswa lain untuk mendiskusikan apa yang telah difikirkannya pada tahap pertama. Interaksi pada tahap ini diharapkan dapat membagi jawaban dengan pasangannya. Biasanya guru memberikan waktu 4-5 menit untuk berpasangan.

Tahap 3 : Share (berbagi)

Pada tahap akhir guru meminta kepada pasangan untuk berbagi jawaban dengan seluruh kelas tentang apa yang telah mereka diskusikan. Ini efektif dilakukan dengan cara bergiliran pasangan demi pasangan dan dilanjutkan sampai sekitar seperempat pasangan telah mendapat kesempatan untuk melaporkan.

Dari beberapa pendapat para ahli di atas maka dapat di simpulkan bahwa langkah-langkah Think-Pair-Share ada tiga yaitu :

1) $\operatorname{Think(berpikir)}$

Guru memberikan suatu topik atau masalah yang di kaitkan dengan pelajaran dan meminta siswa menggunakan waktu beberapa menit untuk berfikir sendiri.

2) Pair (berpasangan)

Selanjutnya guru meminta siswa untuk berpasangan dan mendiskusikan apa yang telah mereka peroleh dan meraka hanya di beri waktu kurang lebih selama 4 hingga 5 menit.

3) Share (berbagi)

Langkah akhir guru meminta pasanganpasangan untuk berbagi dengan keseluruhan kelas yang telah mereka bicarakan.

b. Kelebihan dan Kekurangan Model Pembelajaran Cooperative Learning tipe Think-Pair-Share (TPS)

Kelebihan model pembelajaran ThinkPair-Share (TPS) menurut Assyafi'i adalah:

1) Memberi siswa waktu lebih banyak untuk berfikir, menjawab, dan saling membantu satu sama lain. 
2) Meningkatkan partisipasi akan cocok untuk tugas sederhana.

3) Lebih banyak kesempatan untuk konstribusi masing-masing anggota kelompok.

4) Interaksi lebih mudah.

5) Lebih mudah dan cepat membentuk kelompoknya.

6) Seorang siswa juga dapat belajar dari siswa lain serta saling menyampaikan idenya untuk didiskusikan sebelum disampaikan di depan kelas.

7) Dapat memperbaiki rasa percaya diri dan semua siswa diberi kesempatan untuk berpartisipasi dalam kelas.

8) Siswa dapat mengembangkan keterampilan berfikir dan menjawab dalam komunikasi antara satu dengan yang lain, serta bekerja saling membantu dalam kelompok kecil.

9) Siswa secara langsung dapat memecahkan masalah, memahami suatu materi secara berkelompok dan saling membantu antara satu dengan yang lainnya, membuat kesimpulan (diskusi) serta mempresentasikan di depan kelas sebagai salah satu langkah evaluasi terhadap kegiatan pembelajaran yang telah dilakukan.
10) Memungkinkan merumuskan dan

siswa untuk pertanyaan-pertanyaan mengenai materi yang diajarkan karena secara tidak langsung memperoleh contoh pertanyaan yang diajukan oleh guru, serta memperoleh kesempatan untuk memikirkan materi yang diajarkan.

11) Siswa akan terlatih menerapkan konsep karena bertukar pendapat dan pemikiran dengan temannya untuk mendapatkan kesepakatan dalam memecahkan masalah.

12) Angka putus sekolah berkurang. Model pembelajaran TPS diharapkan dapat memotivasi siswa dalam pembelajaran sehingga hasil belajar siswa dapat lebih baik daripada pembelajaran dengan model konvensional.

13) Sikap apatis berkurang. Sebelum pembelajaran dimulai, kencenderungan siswa merasa malas karena proses belajar di kelas hanya mendengarkan apa yang disampaikan guru dan menjawab semua yang ditanyakan oleh guru. Dengan melibatkan siswa secara aktif dalam proses pembelajaran, metode pembelajaran TPS akan lebih menarik dan tidak monoton dibandingkan metode konvensional. 
14) Penerimaan terhadap individu lebih besar. Dalam model pembelajaran konvensional, siswa yang aktif di dalam kelas hanyalah siswa tertentu yang benar-benar rajin dan cepat dalam menerima materi yang disampaikan oleh guru sedangkan siswa lain hanyalah "pendengar" materi yang disampaikan oleh guru. Dengan pembelajaran TPS hal ini dapat diminimalisir sebab semua siswa akan terlibat dengan permasalahan yang diberikan oleh guru.

15) Hasil belajar lebih mendalam. Parameter dalam PBM adalah hasil belajar yang diraih oleh siswa. Dengan pembelajaran TPS perkembangan hasil belajar siswa dapat diidentifikasi secara bertahap. Sehingga pada akhir pembelajaran hasil yang diperoleh siswa dapat lebih optimal.

Adapun kekurangan model pembelajaran cooperative learaning tipe Think-Pair-Share (TPS)menurut Assyafi'i yaitu ;

1) Membutuhkan koordinasi secara bersamaan dari berbagai aktivitas.

2) Membutuhkan perhatian khusus dalam penggunaan ruangan kelas.
3) Peralihan dari seluruh kelas ke kelompok kecil dapat menyita waktu pengajaran yang berharga. Untuk itu guru harus dapat membuat perencanaan yang seksama sehingga dapat meminimalkan jumlah waktu yang terbuang.

4) Banyak kelompok yang melapor dan perlu dimonitor.

5) Lebih sedikit ide yang muncul.

6) Jika ada perselisihan,tidak ada penengah.

7) Menggantungkan pada pasangan.

8) Jumlah siswa yang ganjil berdampak pada saat pembentukan kelompok, karena ada satu siswa tidak mempunyai pasangan.

9) Ketidaksesuaian antara waktu yang direncanakan dengan pelaksanaannya.

10) Metode pembelajaran think-pair-share belum banyak diterapkan di sekolah.

11) Sangat memerlukan kemampuan dan ketrampilan guru, waktu pembelajaran berlangsung guru melakukan intervensi secara maksimal.

12) Menyusun bahan ajar setiap pertemuan dengan tingkat kesulitan yang sesuai dengan taraf berpikir anak.

13) Mengubah kebiasaan siswa belajar dari yang dengan cara mendengarkan 
ceramah diganti dengan belajar berpikir memecahkan masalah secara kelompok, hal ini merupakan kesulitan sendiri bagi siswa.

14) Sangat sulit diterapkan di sekolah yang rata-rata kemampuan siswanya rendah dan waktu yang terbatas.

15) Jumlah kelompok yang terbentuk banyak.

Pada dasarnya setiap model pembelajaran memiliki kelebihan dan kerangan masing-masing, dalam hal ini dapat disimpulkan bahwa model Cooporative Laerningtipe Think-Pair-Share (TPS) memiliki kelebihan untuk diterapkan dalam pembelajaran karena model ini memberi waktu lebih banyak yang diberikan kepada siswa untuk berfikir, saling menanggapi, dan untuk saling mengkoreksi satu sama lain dari hasil pemikiran individu dam masing-masing kelompok. Selain itu model Cooperative Laerning Tipe ThinkPair-Share (TPS) yang memiliki keefektifan dalam pembentukan kelompok dan pembentukan antar siswa untuk saling berbagi dalam rangka mengembangan pengetahuan. Kemudian semua kelompok diberi kesempatan untuk dapat mempresentasikan hasil diskusinya yang kemudian dapat secara mendalam dalam hal pemahaman materi karena banyaknya pendapat yang ada. Selain itu model Cooporative Laerning Tipe Think-PairShare (TPS) juga memberikan kesempatan kepada siswa untuk aktif dalam proses pembelajaran, hal itu karena siswa yang lebih banyak berperan.

\section{Hasil Belajar}

Setiap roses pembelajaran selalu menghasilkan suatu hasil belajar. Hasil belajar merupakan bukti dari usaha yang telah dilakukan dalan kegiatan belajar dan merupakan bukti dari usaha yang telah dilakukan dalam kegiatan belajar dan merupakan nilai yang diperoleh siswa dari proses pembelajarannya.

Menurut Gagne, (Sumarno, 2011) "hasil belajar merupakan kemampuan internal (kapabilitas) yang meliputi pengetahuan, keterampilan dan sikap yang telah menjadi milik pribadi sesorang dan memungkinkan seseorang melakukan sesuatu".Pendapat lain tentang hasil belajar dikemukakan oleh Briggs (Taruh, 2003: 17) “yang mengatakan bahwa hasil belajar adalah seluruh kecakapan dan hasil yang dicapai melalui proses pembelajaran di sekolah yang dinyatakan dengan angka-angka atau nilainilai berdasarkan tes hasil belajar”. 
Dari pendapat beberapa ahli tersebut dapat penulis simpulkan bahwa yang dimaksud hasil belajar adalah hasil usaha dalam kegiatan pembelajaran di mana hasil belajar tersebut diperoleh sustu perubahan sejumlah pengetahuan, sikap, dan ketrampilan yang berupa nilai atau angka.

a. Ciri-ciri belajar

Menurut Menurut (Sugianto, 2009:40) ciri-ciri pembelajaran cooperative laerning adalah :

a) Saling ketergantungan positif

Saling ketergantungan dapat dicapai memalui saling ketergantungan mencapai tujuan, saling ketergantunan menyelesaikan tugas, saling ketergantungan bahan atau sumber, saling ketergantungan peran dan saling ketergantungan hadiah.

b) Interaksi tatap muka

Interaksi tatap muka akan memaksa peserta didik untuk saling tatap muka dalam kelompok sehingga terjadi suatu dialog.

c) Akuntabilitas individual

Nilai kelompok didasarkan atas rata-rata hasil belajar semua anggota kelompok, karena itu setiap anggota kelompok harus memberikan sumbangan untuk kemajuan kelompok. Penialaian tersebut dimaksudkan untuk akuntabilitas individual.

d) Ketrampilan menjaga hubungan antar pribadi

Peserta didik yang tidak mampu menjalin hubungan antar pribadi akan mendapat teguran dari guru juga dari sesama peserta didik.

Berdasarkan pernyataan tersebut dapat di simpulkan bahwa hasil belajar merupakan tingkat kemampuan siswa dalam pembelajaran yang dapat berupa pernyataan dalam bentuk angka maupun tingkah laku berdasarkan norma acuan, merupakan kapasitas terstruktur dari perubahan individu yang diinginkan berdasar ciri-ciri atau variabel melalui perlakuan pembelajaran tertentu. Hasil belajar merupakan bukti dari usahanya yang telah ditempuh atau dilakukan seseorang dalam kegiatannya, berupa nilai pada akhir pembelajaran.

b. Faktor-faktor yang mempengaruhi hasil belajar

Kemampuan seseorang dalam menguasai sebuah ilmu pengetahuan dan ketrampilan dipengaruhi oleh banyak faktor, dan faktor yang dapat mempengaruhi hasil belajar yaitu faktor ekstern dan faktor intern. Menurut Slameto (2003:54) faktor-faktor 
yang mempengaruhi prestasi belajar banyak jenisnya, tetapi dapat di golongkan menjadi dua, yaitu:

\section{1) Faktor Internal}

yaitu faktor yang ada dalam diri individu yang sedang belajar, faktor intern terdiri dari:

a) Faktor jasmaniah (kesehatan dan cacat tubuh)

b) Faktor psikologis (inteligensi, perhatian, minat, bakat, motif, kematangan dan kesiapan)

c) Faktor kelelahan

2) Faktor Eksternal

yaitu faktor dari luar individu. Faktor ekstern terdiri dari:

a) Faktor keluarga ( cara orang tua mendidik, relasi antara anggota keluarga, suasana rumah, keadaan ekonomi keluarga, pengertian orang tua, dan latar belakang kebudayaan )

b) Faktor sekolah (metode mengajar guru, kurikulum, relasi guru dengan siswa, relasi siswa dengan siswa, disiplin sekolah, alat pelajaran, waktu sekolah, standar belajar diatas ukuran, keadaan gedung, metode belajar dan tugas rumah

c) Faktor masyarakat (kegiatan siswa dalam masyarakat,media massa, teman bergaul, dan bentuk kehidupan masyarakat).

Dari kutipan diatas dapat disimpulkan bahwa ada beberapa faktor yang mempengaruhi hasil belajar yaitu, faktor ekstern dimana faktor ini berasal dari luar diri siswa. Contohnya lingkungan keluarga, lingkungan masyarakat dan lingkungan sekolah, kemudian faktor intern yaitu faktor yang berasal dari dalam diri siswa yang dapat mempengaruhi hasil belajar siswa, contohnya yaitu faktor psikologi, minat, perhatian, motivasi, bakat, kematangan dan kesiapan serta keuletan atau ketelatenan. Keterkaitan terhadap model pembelajaran yang dipilih oleh peneliti dipandang sesuai karena dalam kegiatannya menyelaraskan dari dua faktor diatas.

\section{METODE PENELITIAN}

Penelitian ini merupakan penelitian bersifat pengaruh yaitu mengkaji antara variabel bebas dan variabel terikat. Penelitian ini mencari bagaimana pengaruh penggunaan model pembelajaran Cooperative Laerning Tipe Think-Pair-Share(TPS) terhadap hasil belajar kewirausahaan, metode experimen quasi experimental design jenis kontrol group pre-test post-test dalam desain ini terdapat kelas eksperimen dan kelas 
kontrolyang akan peneliti lihat perbedaan pencapaian antara kedua kelas tersebut. Dalam penelitian ini yang menjadi kelas eksperimen adalah kelas X AK.1 dan yang menjadi kelas kontrol adalah kelas X AK.2.

Dalam penelitian ini yang menjadi populasi adalah seluruh siswa kelas $\mathrm{X}$ akuntansi Semester genap SMK Kartikatama 1 Metro yang terdiri dari 2 kelas yaitu kelas X.AK 1 dan X.AK 2 dengan jumlah 45 siswa yang dapat dilihat pada tabel berikut. Dan sampel penelitian dalam penelitian ini menggunakan dengan cara cluster random sampling yaitu teknik penentuan sampel dengan dengan cara peneliti mencampur objek-objek didalam populasi sehingga semua objek dianggap memiliki kesempatan yang sama untuk diambil sebagai sampel. Sampel dalam penelitian ini adalah kelas X.AK 1 dengan jumlah 24 siswa sekaligus menjadi kelas eksperimen dan yang menjadi kelas kontrol dalam penelitian ini adalah kelas X.AK 2 dengan jumlah 21 siswa.

Setiap peneliti memerlukan metode pengumpulan data yang tepat sehingga kegiatan penelitian yang dilakukan berhasil mengumpulkan data dapat dipertanggung jawabkan baik secara teori maupun sesuai penelitian metode yang digunakan untuk mengumpulkan data adalah observasi, wawancara, dokumentasi, dan test.

Sebelum analisis data dilakukan, instrumen diuji yaitu uji perysaratan instrumen validitas dan reliabilitas. Uji validitas menggunakan rumus korelasi Pearson Product Moment dan uji reliabilitas menggunakan KR-20.

Setelah data terkumpul, selanjunya data tersebut dianalisis, data yang dikumpulkan adalah data kuantitatif (berupa nilai angka) dari hasil belajar siswa yang telah diberi perlakuan model pembelajaran Cooperative Learning Tipe Think-Pair-Share (TPS) dari masing-masing sampel. Dalam penelitian ini yang akan di gunakan dalam menganalisis data tersebut adalah meliputi uji normalitas dan uji homogenitas. Rumus yang digunakan untuk menguji uji normalitas dan uji homogenitas adalah menurut Sudjana (2005:239).

\section{PEMBAHASAN HASIL PENELITIAN}

Dalam penelitian ini data hasil belajar meliputi dua macam yaitu data yang diperoleh dari hasil pre-test dan data hasil post-test.Nilai-nilai dari hasil belajar kewirausahaan siswa dari evaluasi uji pretest ataupun post-test, setelah diberikan JURNAL PROMOSI 31 Jurnal Pendidikan Ekonomi UM Metro 
treatment model pengaruh Penggunaan Model Pembelajara Coopeative Learning Tipe Think-Pair-Share(TPS).

Berdasarkan hasil analisis data diketahui bahwa pada tahap evaluasi uji pre-test, bahwa siswa yang mencapai tuntas belajar hanya $20,83 \%$ atau 5 siswa, sedangkan siswa yang belum mencapai tuntas belajar adalah 79,17\% atau 19 siswa. Dengan demikian dapat ditemukan bahwa jumlah siswa yang belum tuntas belajar atau belum mencapai standar ketuntasan yang telah ditetapkan masih banyak yaitu 79,17 \% atau 19 siswa dari total keseluruhan siswa sebanyak 24 siswa. Dari tabel tersebut dapat menunjukkan juga bahwa pada tahap evaluasi post-test, setelah siswa mendapatkan treatment atau perlakuan model pengaruh pembeajaran Cooperative Learning Tipe Think-Pair-Share(TPS) yang mencapai tuntas belajar berjumlah 58,33\% yaitu 14 siswa, sedangkan siswa yang belum mencapai tuntas belajar berjumlah $41,64 \%$ yaitu 10 siswa, dari total keseluruhan siswa sebanyak 24 siswa.

Dalam penelitian ini setelah siswa mendapatkan treatment atau perlakuan model pengaruh pembelajaran Cooperative Learning Tipe Think-Pair-Share(TPS) hasil belaiar kewirausahaan mengalami 32 JURNAL PROMOSI Jurnal Pendidikan Ekonomi UM Metro peningkatan dilihat dari perbandingan pada evaluasi pre-test dan evaluasi post-test, yaitu siswa yang mencapai kriteria ketuntasan minimal pada evaluasi pre-test adalah $20,83 \%$ atau 5 siswa dari total keseluruhan siswa sebanyak 24 siswa, sedangkan siswa yang mencapai kriteria

ketuntasan minimal pada evaluasi post-test adalah 58,33\% atau 14 siswa, dari total keseluruhan siswa sebanyak 24 siswa. Secara keseluruhan bahwa setelah siswa mendapatkan treatment atau perlakuan model pengaruh penggunaan model pembelajaran Cooperative Learning Tipe Think-Pair-Share(TPS) hasil belajar kewirausahaan mengalami peningkatan.

\section{KESIMPULAN}

Berdasarkan penelitian yang telah dilakukan penulis, maka dapat disimpulkan bahwa hasil pengumpulan data yang dikumpulkan dari 24 siswa yang diberikan perlakuan (treatmentI) dengan model Cooperatove Learning Tipe Think-PairShare(TPS). Hasil belajar kewirausahaan siswa yang masuk dalam kategori tuntas sebanyak 66,67\% yaitu 16 siswa dan yang belum tuntas $33,33 \%$ yaitu 8 siswa.

Pada pengujian yang menggunakan rumus regresi linier sederhana dineroleh $\alpha$ 
22,8804, $\mathrm{b}=0,7732$ sehingga demikian $\overline{\mathrm{Y}}=$ $\alpha+b X$ adalah $\mathrm{Y}=22,8804+0,7732 \mathrm{X}$ kemudian dari hasil analisis diperoleh bahwa ada pengaruh yang positif model Cooperatove Learning Tipe Think-PairShare(TPS) terhadap hasil belajar kewirausahaan siswa kelas X AK 1 SMK Kartikatama 1 metro. Hal ini dibuktikan dengan analisis bahwa $t_{\text {hitung }}>\mathrm{T}_{\text {tabel }}$ dan terlihat pada taraf signifikan $5 \%$ adalah $9,10>1,72$ dab pada taraf signifikan $1 \%$ yaitu $9,10>2,51$ yang dapat dilihat pada daftar $\mathrm{G}$ statistik, dengan demikian maka hipotesis diterima. Jadi "ada pengaruh yang positif penggunaan model Cooperatove Learning Tipe Think-Pair-Share (TPS) terhadap hasil belajar kewirausahaan siswa kelas X AK 1 SMK Kartikatama 1 Metro tahun pelajaran 2015/2016.

Berdasarkan kesimpulan yang diperoleh selama melaksanakan penelitian dan hasil pengamatan dalam penelitian, maka penulis mencoba mengemukakan saran-saran guna meningkatkan hasil belajar siswa dalam mata pelajaran kewirausahaan sebagai berikut:

1) Untuk meningkatkan hasil belajar siswa, bagi guru sebagai pelaksana proses pembelajaran peneliti menyarankan agar guru memilih model pembelajara yang tepat untuk meningkatkan hasil belajar kewirausahaan, khususnya dengan menggunakan model Cooperatove Learning Tipe Think-Pair-Share(TPS) pada materi mengelola konflik karena model pembelajaran ini siswa dapat bekerjasama dengan aktif dan baik secara individu maupun secara kelompok guna meningkatkan hasil belajar siswa pada mata pelajaran kewirausahaan.

2) Untuk meningkatkan hasil belajar siswa pada mata pelajaran kewirausahaan disarankan bagi siswa agar dapat mengikuti proses pembalajaran dengan baik, dalam rangka meningkatkan hasil belajar dengan adanya model pembelajaran Cooperatove Learning Tipe Think-Pair-Share(TPS). Secara lebih aktif, kreatif, secara mandiri dalam menerima dan mengolah materi pembelajaran dengan baik yang di berikan oleh guru sehingga dapat berpengaruh terhadap hasil belajar.

3) Untuk meningkatkan hasil belajar siswa, disarankan bagi sekolah agar dapat mengarahkan, memotivasi, dan mendukung para guru untuk meningkatkan kualitas proses pembelajaran melalui penggunaan 
model pembelajaran yang tepat. Sebagai wujud upaya untuk meningkatkan hasil belajar peserta didik.

\section{DAFTAR PUSTAKA}

Alfabeta, Slameto. 2003. Belajar dan Faktor-Faktor yang Mempengaruhinya. Jakarta. PT. Rineka Cipta.

Alim, Sumarno. 2011. Pemanfaatan ICT Dalam Proses Merancang Dan Mengimplementasikan Model Pembelajaran Inovatif Designed Student Centred Instructional. From http://elearning.unesa.ac.id/myblog/ali msumarno/ (Jum'at, 7 Desember 2012, Pukul 10.00 WIB).

Ibrahim, M. Et, All. 2000. Pembelajaran Kooperatif. Surabaya: Universitas Negeri Surabaya Press.

Lie, Anita. 2002. Cooperative Learning. Jakarta: Grasindo

Rosmini, Dkk.2009. JenisPembelajaran Cooperative Learning. Http://Ktiptk.Blogspirit. Com/ Archive/01/2004/Ketuntasan-Belajar. Html. Di Kutip Pada_Tanggal 20 Agustus 2015 Pukul 15.30 WIB

Sudjana. 2005. Metode Statistika. Bandung: PT Tarsito. Bandung

Sugianto dkk. 2014. Perbedaan Penerapan Model Pembelajaran Kooperatif Tipe Jigsaw dan STAD Ditinjau dari Kemampuan Penalaran dan Komunikasi Matematis Siswa SMA. Jurnal Didaktik Matematika. Jurnal Pendidikan Ekonomi UM Metro
Universitas Negeri Medan. [Online]. Tersedia http://www.jurnal.unsyiah.ac.id/DM/

Taruh, Enos. 2003. Konsep Diri dan Motivasi Berprestasi dalam Kaitannya dengan Hasil Belajar Fisika. Jurnal Penelitian dan Pendidikan (hlm.15-29) Gorontalo: IKIP Negeri Gorontalo.

Universitas Muhammadiyah Metro.2015. Pedoman Penulisan Karya Ilmiah Edisi Revisi 3. UM Metro. 